\title{
Optimization of hemolysin formation in Alcaligenes species isolated from abattoir wastewater samples in Akure, Ondo State, Nigeria
}

\author{
${ }^{*}$ Olubukola O. Olusola-Makinde ${ }^{1,2,3}$, Daniel J. Arotupin ${ }^{1}$, Anthony I. Okoh ${ }^{2,3}$ \\ ${ }^{1}$ Dept. of Microbiology, Federal University of Technology, Akure, Nigeria \\ ${ }^{2}$ SAMRC Microbial Water Quality Monitoring Centre, \\ University of Fort Hare, Alice, South Africa \\ ${ }^{3}$ Applied and Environmental Microbiology Research Group (AEMREG), \\ University of Fort Hare, Alice, South Africa
}

*Corresponding author: ooolusola-makinde@futa.edu.ng

\begin{abstract}
Hemolysin is significantly toxic and is used as a molecular marker for pathogenicity. This study evaluates the conditions for optimal hemolysin production by Alcaligenes faecalis strains isolated from a city abattoir wastewater. The parameters investigated for hemolysin formation were the size of the inoculum, initial $\mathrm{pH}$ of the production medium, bacterial incubation temperature, agitation speed, and growth media. After that, the effect of various parameters on the hemolytic activity for the formation of hemolysin was assessed. The genus Alcaligenes was assigned to the test organisms after analyzing their 16S rRNA gene sequence with accession numbers: MF498824, MF498825, and MF498827. Optimum conditions for hemolysin formation in Alcaligenes faecalis strain OS42 were inoculum size of $0.5 \%(\mathrm{v} / \mathrm{v}), \mathrm{pH} 9,20^{\circ} \mathrm{C}, 0 \mathrm{rpm}$, and brain heart infusion broth. $77 \%$ and $79 \%$ of Hemolytic activities were achieved at $20 \mathrm{~h}$ for strains OS42 and OS61. Cholesterol and ethylenediaminetetraacetic acid did not affect hemolysin formation. This work revealed that the hemolysin formation in Alcaligenes strains was sourced from abattoir wastewater effluent. The effluent was contaminated with pathogenic Alcaligenes strains, a public health hazard to their prospective infection of humans and animals.
\end{abstract}

Keywords: Abattoir wastewater; Alcaligenes spp.; hemolysin; optimization; pathogenicity

\section{Introduction}

Alcaligenes faecalis is a well-reported environmental bacterium associated with freshwaters (Nduka, 2011), soil (Jiajun et al., 2010), wastewaters (Rajeshkumar \& Jayachandran, 2004; AboAmer et al., 2015), and mangrove sediments (Wongwongsee et al., 2003; Behera et al., 2017). Alcaligenes faecalis synthesizes various ranges of extracellular proteins such as biosurfactant, enzymes, R-(-) mandelic acid, and the enterococcal surface protein (Wongwongsee et al., 2003; Tapi et al., 2010; Bharali et al., 2011; Xia, 2013 and Ju et al., 2016). The growth of Alcaligenes species is easily stimulated in water with the addition of proteins (Nduka, 2011). More so, the abattoir wastewater consists of a high number of organic matters such as blood, animal fats, aborted fetuses, condemned organs, bile, urine, and undigested feed that can stimulate the growth of most bacteria, including Alcaligenes species (Chukwu et al., 2008 and Ogbonna, \& Ideriah, 2014). Blood is the primary organic matter in the abattoir wastewater comprising hemoglobin, an 
iron-containing compound that can be lysed by hemolysin produced by hemolytic microorganisms (Coker et al., 2001).

Hemolysins are exotoxins that lyse erythrocytes in vitro by disintegrating their cell membrane (Stipcevic et al., 2005; Das et al., 2016). Their production is attributed to the microorganisms' virulence factor that produces them. Nevertheless, Rajesh et al. (2013) has reported hemolytic activity in non-pathogenic Streptomyces coelicolor M145. Besides red blood cells, hemolysins can target other cells, including white blood cells (Stipcevic et al., 2016). Some hemolytic organisms also show the ability to utilize nicotinamide adenine dinucleotide (NAD) (factor V) and heme (factor X) released when blood is lysed (Public Health England, 2015). Hemolysin's production is attributed to various functions, such as the growth of the respective microbe (Zhang et al., 2005 and Singh et al., 2010) and heme uptake in mycobacteria (Jones \& Neiderweis, 2011).

The abattoir generates a large amount of wastewater that constitutes $32.5 \%$ of blood (Aniebo et al., 2011). In addition, the primary wastewater treatment, which entails mainly segregation, is applied at the Onyearugbulem abattoir; thus, a high blood concentration is associated with its final effluent (Akinro et al., 2009). Furthermore, there is little documentation on hemolysin production by environmental bacterial strains, specifically from the abattoir.

This paper, therefore, describes hemolysin production by Alcaligenes strains isolated from Onyearugbulem abattoir effluent and the optimal culture conditions for hemolysin production by Alcaligenes faecalis strains isolated from abattoir wastewater. In addition, this study further provides information on the influence of different treatments on hemolysin production. This is the first report on optimizing hemolysin produced by Alcaligenes strains to our knowledge.

\section{Materials and methods}

\subsection{Source and isolation of bacterial isolates}

Final wastewater effluent samples from the Onyearugbulem abattoir $\left(7^{\circ} 16^{\prime} 58.5^{\prime \prime} \mathrm{N} 5^{\circ} 11^{\prime} 15.9^{\prime \prime} \mathrm{E}\right)$ were collected over a 12-month sampling regime and analyzed within $4 \mathrm{~h}$ of collection. For the bacterial isolation, serial dilution of the samples was prepared, and $1 \mathrm{ml}$ was pipetted into sterile prepared nutrient agar (Biolab) plates using the spread-plate method and cultured aerobically at 37 ${ }^{\circ} \mathrm{C}$ for $24 \mathrm{~h}$. Distinct colonies were sub-cultured on sterile nutrient agar (Biolab) plates at $37{ }^{\circ} \mathrm{C}$ for $24 \mathrm{~h}$. The pure cultures were aseptically transferred into well-labeled nutrient agar (Biolab) slants and preserved at $4{ }^{\circ} \mathrm{C}$ until further studies.

\subsection{Phenotypic characterization of isolates}

The method described by Hussain et al. (2013) was applied for the phenotypic characterization of the isolates with a slight modification. Bergey's manual of systematic bacteriology was employed to suggest the phenotypic characteristics of the bacterial isolates. The assessed cultural features included the colonial color, shape, edge, elevation, and surface, while catalase, coagulase, oxidase, indole, motility, and sugars' fermentation tests were carried out for the biochemical characterization. In addition, gram-stain reactions were assayed to ascertain morphological characteristics. 


\subsection{Genetic characterization of bacterial isolates by $16 \mathrm{~S}$ rRNA}

WITH MINOR REVISIONS, the DNA extraction and 16S rRNA gene amplification were implemented, as reported by El Samak et al. (2018). Briefly, two colonies of an overnight bacterial culture were aseptically reconstituted in $200 \mu 1$ sterile nuclease-free water. The cells were vortexed and lysed by boiling $\left(100^{\circ} \mathrm{C}\right)$ for 10 min using AccuBlock (Digital dry bath, Labnet). The lysate (supernatant) containing the DNA was recovered at $14,000 \mathrm{rpm}$ for $4 \mathrm{~min}$ in a Mini Spin microcentrifuge (LASEC, RSA). Cell lysates were preserved at $4^{\circ} \mathrm{C}$ and functioned as DNA stencils in polymerase chain reaction (PCR) assays. Two universal primers; 27F (Forward primer 5'-AGAGTTTGATCCTGGCTCAG-3') and 1492R (Reverse primer 5'GGTTACCTTGTTACGACTT-3'), were used for the amplification of isolates' 16S rRNA gene with the aid of PCR. The conditions employed for PCR amplification included: initial denaturation for $15 \mathrm{~min}$ at $95{ }^{\circ} \mathrm{C}, 35$ cycles at $95^{\circ} \mathrm{C}$ for $30 \mathrm{sec}, 61^{\circ} \mathrm{C}$ for $1 \mathrm{~min}$, and at $72{ }^{\circ} \mathrm{C}$ for $1 \mathrm{~min} 30 \mathrm{sec}$. Lastly, an extension step at $72{ }^{\circ} \mathrm{C}$ for $10 \mathrm{~min}$. For verification, amplicons were resolved in a $1.5 \%$ agarose gel electrophoresis at 120 Volts for $35 \mathrm{~min}$ in $0.5 \%$ TBE buffer stained with ethidium bromide solution. Sequencing the resolved PCR outcomes was done at the University of Kwa Zulu Natal, Durban, South Africa. The deoxyribonucleic acid (DNA) sequences were analyzed by the algorithm system of the Basic Local Alignment Search Tool (BLAST) from the National Centre for Biotechnology (NCBI) (http://www.ncbi.nlm.nih.gov/Blast.cgi). The sequences from the GenBank database with more than $98 \%$ similarity and the resultant sequences were copied in FASTA format and used to determine the phylogeny of the bacterial strains. The software used for the phylogeny studies was Molecular Evolutionary Genetics Analysis version 7.0 (MEGA7).

\subsection{Hemolysin tube assay}

\subsubsection{Collection of hemolysins}

The hemolysin collection from the bacterial cultures was carried out using the descriptions reported by Sato et al. (2012), with minor revisions. Single colony bacterial isolates were cultured at $37{ }^{\circ} \mathrm{C}$ using a blood agar base (Biolab, Hungary) with 5\% defibrinated sheep blood for $24 \mathrm{~h}$. They are used to inoculate brain heart infusion broth (Biolab, Hungary). The inoculated agar plates were cultured at $37^{\circ} \mathrm{C}$ for $18 \mathrm{~h}$ and centrifuged at $12000 \mathrm{rpm}$ for $10 \mathrm{~min}$ at $5{ }^{\circ} \mathrm{C}$. A $0.22 \mu \mathrm{m}$ pore size nylon filter (Micron Separations, Westboro, USA) was used to filter the supernatant. The supernatant (cell-free) was used to evaluate the hemolytic activity of the hemolysin synthesized by the bacterial isolates.

\subsubsection{Determination of hemolytic activity}

With minor revisions, the tube assay for hemolytic activity was adopted as described by Ktari et al. (2017). Freshly collected sheep blood was obtained into sterilized screw cap bottles containing anticoagulant solution (EDTA solution). Five milliliters $(5 \mathrm{ml})$ of heparinized sheep blood was pipetted into $15 \mathrm{ml}$ conical bottle and spun down at $4000 \mathrm{rpm}$ at $4{ }^{\circ} \mathrm{C}$ for $10 \mathrm{~min}$, and the serum was gently aspirated. The bacterial cells were twice washed with normal saline followed by phosphate-buffered saline (PBS) formulated by $137 \mathrm{mM} \mathrm{NaCl}, 2.7 \mathrm{mM} \mathrm{KCl}, 10 \mathrm{mM} \mathrm{Na} 2 \mathrm{HPO}_{4}$, and $1.8 \mathrm{mM} \mathrm{KH}_{2} \mathrm{PO}_{4}$ and $\mathrm{pH}$ adjusted to 6.8 . Before aspiration, the resultant solution (4 $\left.\mathrm{ml}\right)$ was 
diluted with $10 \mathrm{ml}$ of PBS. Subsequently, $1 \% \mathrm{v} / \mathrm{v}$ erythrocytes were prepared with PBS at a ratio of $0.15: 14.85$. For the preparation of bacterial samples, 18 hold bacterial cultures in brain heart infusion broth were standardized $\left(\mathrm{A}_{600 \mathrm{~nm}}=0.1\right)$, whereas $1 \% \mathrm{v} / \mathrm{v}$ of the culture was cultured in nutrient broth (Biolab) at $37{ }^{\circ} \mathrm{C}$ for $24 \mathrm{~h}$. The bacterial culture solution was centrifuged (12000 $\mathrm{rpm}, 10 \mathrm{~min}$ ), and the supernatant was gently aspirated. After that, the hemolysin tube assay was carried out by incubating $500 \mu 1$ of $1 \% \mathrm{v} / \mathrm{v}$ erythrocytes and $500 \mu 1$ of bacterial supernatant at 37 ${ }^{\circ} \mathrm{C}$ for 90 min. Positive control was Triton X-100 (1\%), while negative control was PBS buffer. The mixture was centrifuged $\left(4000 \mathrm{rpm}, 4^{\circ} \mathrm{C}, 5 \mathrm{~min}\right), 100 \mu 1$ of aspirated supernatant was pipetted into microtitre plates, and the absorbance $400 \mathrm{~nm}$ was taken using a microtitre reader (BioTek Instruments, USA). One hemolytic unit (HU) was equalized as the percentage of lysed cells, which was determined by Equation 1.

$$
H U(\%)=\frac{X-X_{0}}{X_{100}-X_{0}} \times 100
$$

where $\mathrm{X}=$ sample absorbance, $\mathrm{X}_{0}=$ negative control absorbance, and $\mathrm{X}_{100}=$ positive control absorbance.

\subsection{Determination of optimal parameters for hemolysin production}

Optimization of hemolysin production by the selected bacterial isolates was carried out by a onevariable-per-time optimization method described by Fatokun et al. (2016).

\subsubsection{Influence of bacterial inoculum size on hemolysin production}

Brain heart infusion broth was inoculated with bacterial culture (18 hold) at varying percentages $(0.5 \%, 1 \%, 2 \%, 3 \%$ and $4 \%)$ standardized to 0.10 at $600 \mathrm{~nm}$ and incubated at $37{ }^{\circ} \mathrm{C}$ for $24 \mathrm{~h}$. Using the hemolysin tube assay, the gently aspirated supernatant, representing the crude enzyme, was assayed for hemolytic activity.

\subsubsection{Influence of initial $\mathrm{pH}$ of the production medium on the hemolysin production}

The growth media's initial $\mathrm{pH}$ was tuned to different $\mathrm{pH}$ values of $3,5,7,9$, and 11 using $1 \mathrm{M}$ $\mathrm{NaOH}$ or $1 \mathrm{M} \mathrm{HCl}$ as necessary before the sterilization. The sterilized media were inoculated with a standardized $\left(\mathrm{A}_{600 \mathrm{~nm}} \approx 0.01\right)$ bacterial culture. The medium was cultured for $24 \mathrm{~h}$ at $37^{\circ} \mathrm{C}$, and the supernatant served as the crude enzyme fraction and was tested for hemolytic activity using the hemolysin tube assay.

\subsubsection{Influence of temperature of bacterial incubation on hemolysin production}

To evaluate the optimal incubation temperature required for hemolysin synthesis, the growth medium was inoculated with a standardized $\left(\mathrm{A}_{600 \mathrm{~nm}} \approx 0.01\right)$ bacterial culture and incubated at the following temperatures: $20,25,30,35$, and $40{ }^{\circ} \mathrm{C}$ for $24 \mathrm{~h}$. After incubation, the supernatant served as the crude enzyme and was tested for hemolytic activity using the hemolysin tube assay.

\subsubsection{Influence of agitation speed on hemolysin production}

To determine the optimal agitation rate, brain heart Infusion broth (Biolab, Hungary) was inoculated with the standardized $\left(\mathrm{A}_{600 \mathrm{~nm}} \approx 0.01\right)$ bacterial culture and incubated under variable 
agitation speed at $37{ }^{\circ} \mathrm{C}$ for $24 \mathrm{~h}$. The agitation speeds included static $(0 \mathrm{rpm})$, slow $(50 \mathrm{rpm})$, standard (100 and $150 \mathrm{rpm})$, and fast agitation $(200 \mathrm{rpm})$. After incubation, the supernatant served as the crude enzyme and was tested for hemolytic activity using the hemolysin tube assay.

\subsubsection{Influence of growth media on hemolysin production}

For the optimal growth media required for hemolysin production, standardized $\left(\mathrm{A}_{600 \mathrm{~nm}} \approx 0.01\right)$ bacterial culture was inoculated in different growth media, [nutrient broth (Biolab, Hungary), blood agar base (Biolab, Hungary) broth, and brain heart infusion broth (Biolab, Hungary) after standardization $\left(\mathrm{A}_{600 \mathrm{~nm}} \approx 0.01\right)$ and incubated for $24 \mathrm{~h}$ at $37^{\circ} \mathrm{C}$. The supernatant was tested for hemolytic activity using the hemolysin tube assay.

\subsection{Time and growth kinetics of hemolysin production}

The relationship between bacterial growth and hemolysin production over a while was investigated as reported by Sato et al. (2012) with minor alterations. Briefly, $1 \mathrm{ml}$ of $18 \mathrm{~h}$ pre-culture cell solution at $0.10 \mathrm{OD}_{600}$ was transferred to $100 \mathrm{ml}$ brain heart infusion broth and cultured for $56 \mathrm{~h}$, under optimal conditions for hemolysin production. The growth medium was withdrawn at $4 \mathrm{~h}$ intervals to determine bacterial growth and hemolytic activity. Culture turbidity at $600 \mathrm{~nm}$ was taken to measure bacterial growth, and hemolytic activity was determined by hemolysin tube assay, as mentioned earlier.

\subsection{The effect of various treatments on the hemolytic activity}

The stimulating effect of cholesterol, EDTA, $\mathrm{AlCl}_{3}, \mathrm{MgCl}_{2}, \mathrm{NaCl}, \mathrm{CaCl}_{2}$, and $\left(\mathrm{NH}_{4}\right)_{2} \mathrm{SO}_{4}$ on the hemolytic activity of hemolysin produced by Alcaligenes strains was evaluated as described by Sato et al. (2012), with minor modifications. Briefly, $10 \mu \mathrm{g} / \mathrm{ml}$ cholesterol, EDTA (0.1 mM), $\mathrm{AlCl}_{3}$ (5 mM), $\mathrm{MgCl}_{2}(5 \mathrm{mM}), \mathrm{NaCl}(5 \mathrm{mM}), \mathrm{CaCl}_{2}(5 \mathrm{mM})$ and $\left(\mathrm{NH}_{4}\right)_{2} \mathrm{SO}_{4}(5 \mathrm{mM})$ were prepared and incubated individually with $5 \mathrm{ml}$ aliquots of freshly collected crude hemolysin for $10 \mathrm{~min}$ and set at $37^{\circ} \mathrm{C}$. Five milliliters of freshly collected crude hemolysin, without any treatment, served as a positive control.

\subsection{Statistical analysis}

The data were obtained in triplicates, and analysis of variance (ANOVA) was determined. Means of the treatment were obtained using Duncan's New Multiple Range Test at a 95\% confidence level using SPSS (version 23).

\section{Results}

\subsection{Molecular confirmation of bacterial isolates}

Analyses of the 16S rRNA gene sequences of bacterial isolates using the BLAST program ascribed the organisms to the Alcaligenes genus. After depositing the 16S rRNA gene sequences at the GenBank, the assigned nomenclatures were identified as Alcaligenes feacalis strains OS42, OS61, and OS117 with accession numbers MF498824, MF498825, and MF498827, respectively. The 
unrooted phylogenetic tree indicating the evolutionary relationships of Alcaligenes strains in this study with other Alcaligenes species available in the NCBI database is shown in Figure 1. Alcaligenes feacalis OS61 had 99\% similarity to Alcaligenes sp. strain SCU-M2.

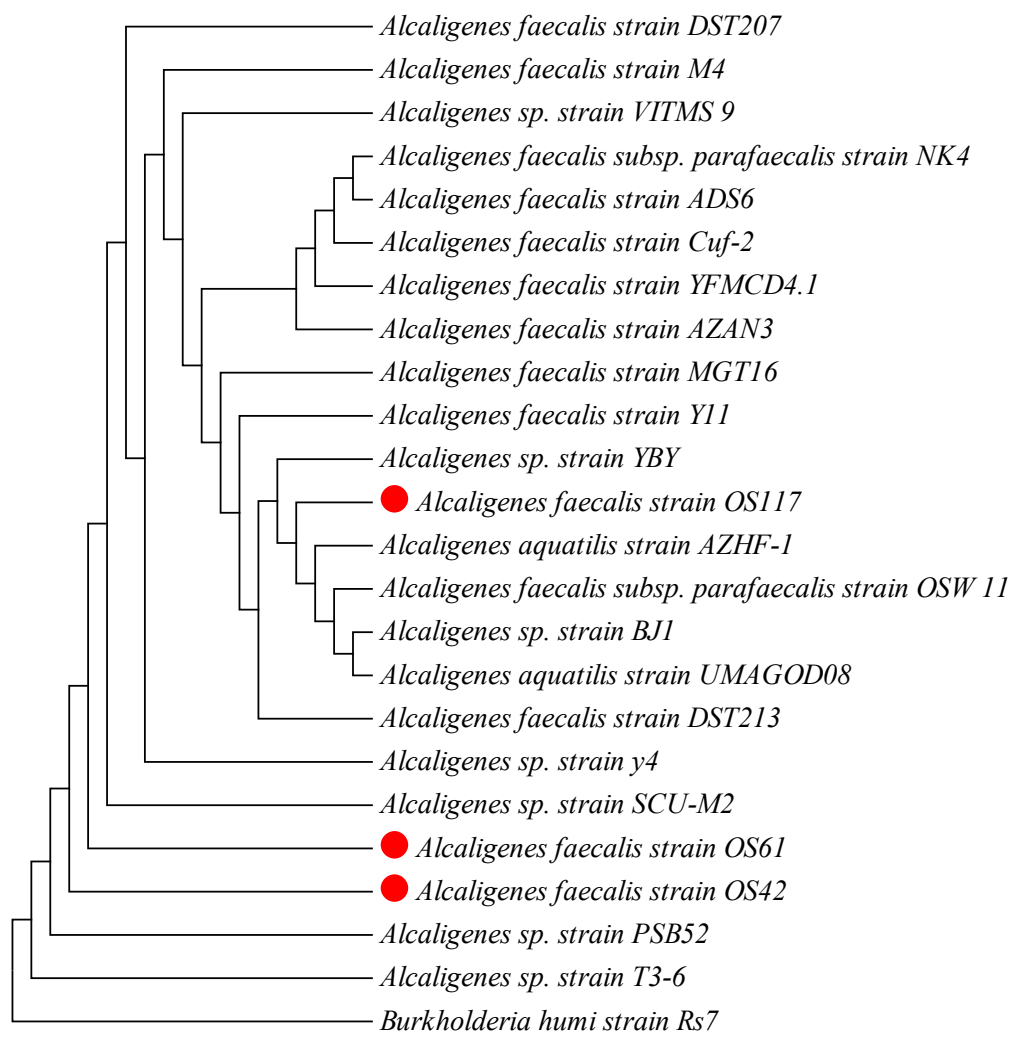

Fig. 1. Phylogeny of the relationship of Alcaligenes feacalis strains OS 42, 61, and 117 (bulleted) with certain Burkholderiales in GenBank database.

3.2 Influence of bacterial inoculum size on hemolysin production

The impact of bacterial inoculum size on hemolysin synthesis was investigated, and the results are shown in Figure 2. Optimal hemolysin production (35.96\%) compared to $100 \%$ hemolysis by Triton-X 100 was attained with $2 \% \mathrm{v} / \mathrm{v}$ inoculum size of Alcaligenes faecalis OS61. Alcaligenes faecalis strains OS42 and OS1 17 had the highest hemolysin formation with $0.5 \% \mathrm{v} / \mathrm{v}$ and $1 \% \mathrm{v} / \mathrm{v}$ inoculum sizes. Triton-X 100 functioned as the positive control. It was observed that hemolysin formation depended on the inoculum sizes $(0.5 \%, 1 \%, 3 \%$, and $4 \%)$.

\subsection{Influence of initial $\mathrm{pH}$ on hemolysin formation}

The influence of initial $\mathrm{pH}$ on hemolysin synthesis by Alcaligenes strains was assessed, and the results are shown in Figure 3. Hemolysin synthesis was studied at variable $\mathrm{pH}$, and the optimal hemolysin formation was obtained at $\mathrm{pH} 9$ for Alcaligenes faecalis OS42, $\mathrm{pH} 7$ for Alcaligenes faecalis OS61 and Alcaligenes faecalis OS117. There was a significant difference among tested $\mathrm{pH}$ ranges $(\mathrm{p}<0.05)$ for hemolysin formation in Alcaligenes faecalis OS42. Furthermore, a steep decline of up to $50 \%$ in hemolysin formation was observed at $\mathrm{pH} 11$ from Alcaligenes faecalis OS42 and Alcaligenes faecalis OS61. 


\subsection{Effect of bacterial incubation temperature on hemolysin formation}

The impact of incubation temperature on the hemolytic activity of the bacterial isolates was studied, and the results are shown in Figure 4. The optimal hemolysin formation was recorded at $25^{\circ} \mathrm{C}$ for Alcaligenes faecalis strains OS61 and OS117, but the appearance was also observed at all other studied incubation temperatures $\left(20^{\circ} \mathrm{C}, 30{ }^{\circ} \mathrm{C}, 35^{\circ} \mathrm{C}\right.$ as well as $\left.40{ }^{\circ} \mathrm{C}\right)$. No significant difference in hemolysin formation at variable incubation temperatures was observed for Alcaligenes feacalis OS42.

\subsection{Influence of agitation speed on hemolysin formation}

The influence of agitation speed on hemolysin formation in Alcaligenes strains was assessed, and the results are presented in Figure 5. The hemolysin formation was little affected at variable agitation speeds, and its optimal formation was recorded at $0 \mathrm{rpm}$ (static) for Alcaligenes faecalis strains OS41 and OS117. $200 \mathrm{rpm}$ was recorded to be the most suitable for Alcaligenes faecalis strains OS61.

\subsection{Influence of growth media on hemolysin formation}

The impact of growth media composition on the synthesis of hemolysin by Alcaligenes faecalis strains was studied, and the results are presented in Figure 6. Alcaligenes faecalis strains OS42 and OS 117 preferred brain heart infusion broth more than other substrates for hemolysin formation with $19.13 \%$ and $99.89 \%$, respectively. On the other hand, the nutrient broth was most suitable for hemolysin for Alcaligenes faecalis strains OS61 (112.38\%).

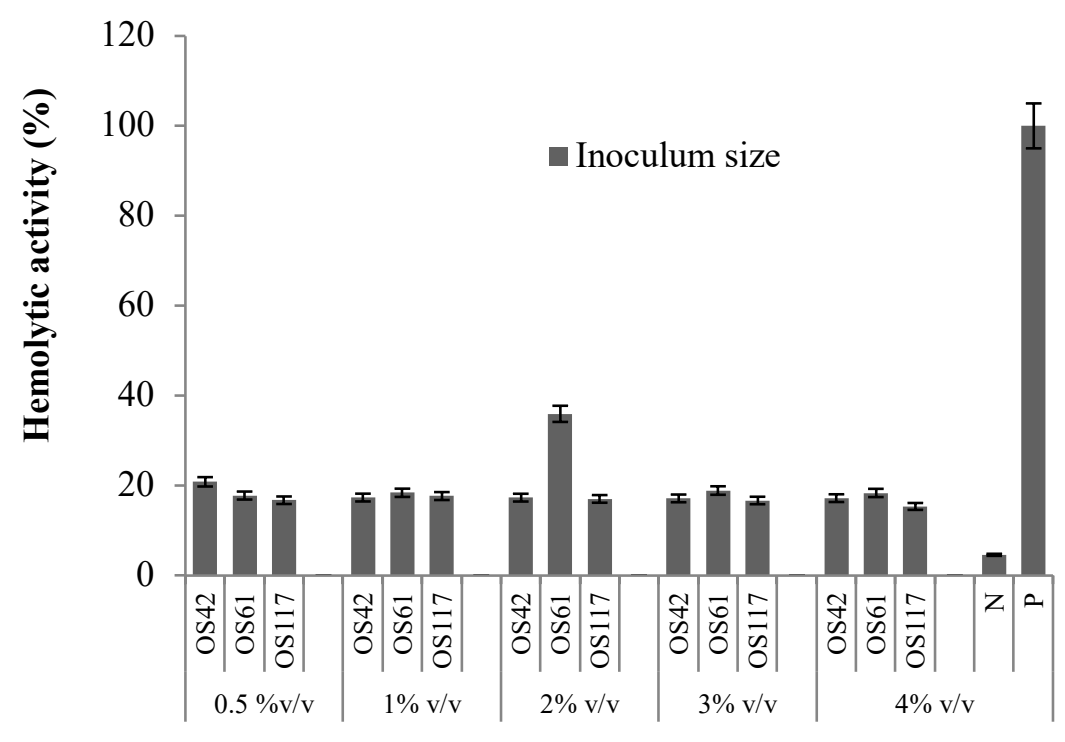

Error bars: $\pm 1 \mathrm{SE}$

Fig. 2. Influence of bacterial inoculum size on hemolysin formation; $\mathrm{N}=$ negative control, $\mathrm{P}=$ positive control 


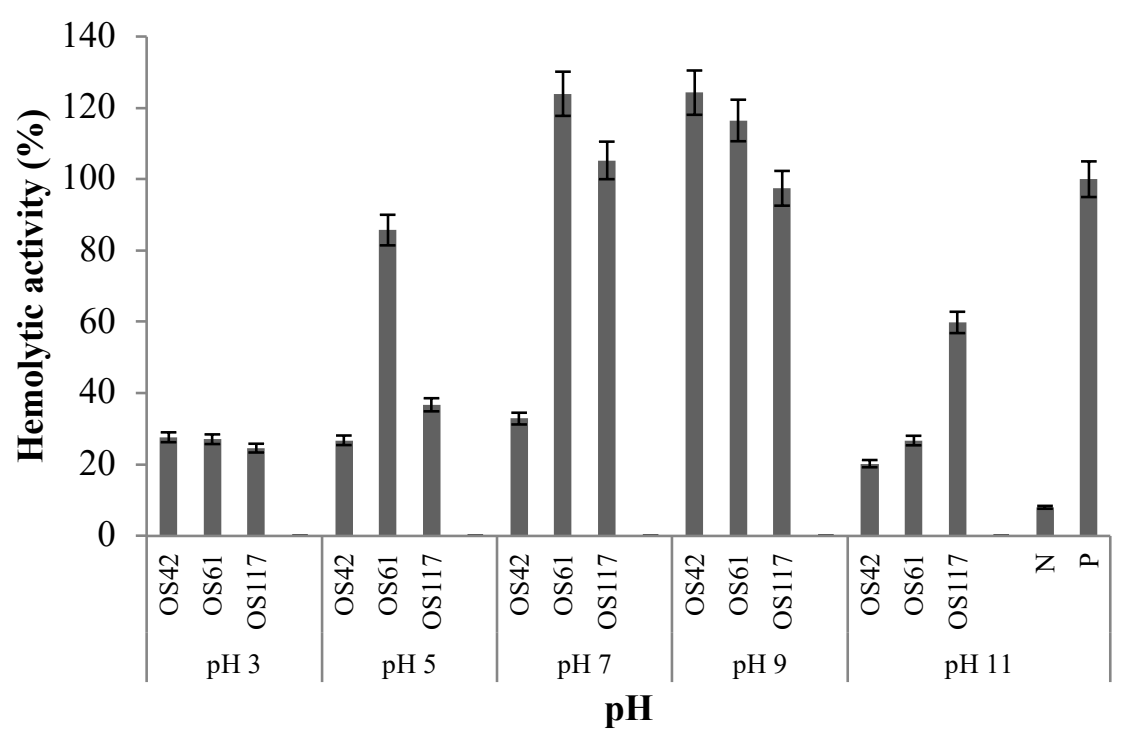

Error bars: $\pm 1 \mathrm{SE}$

Fig. 3. Influence of $\mathrm{pH}$ on hemolysin formation; $\mathrm{N}=$ negative control,

$\mathrm{P}=$ positive control

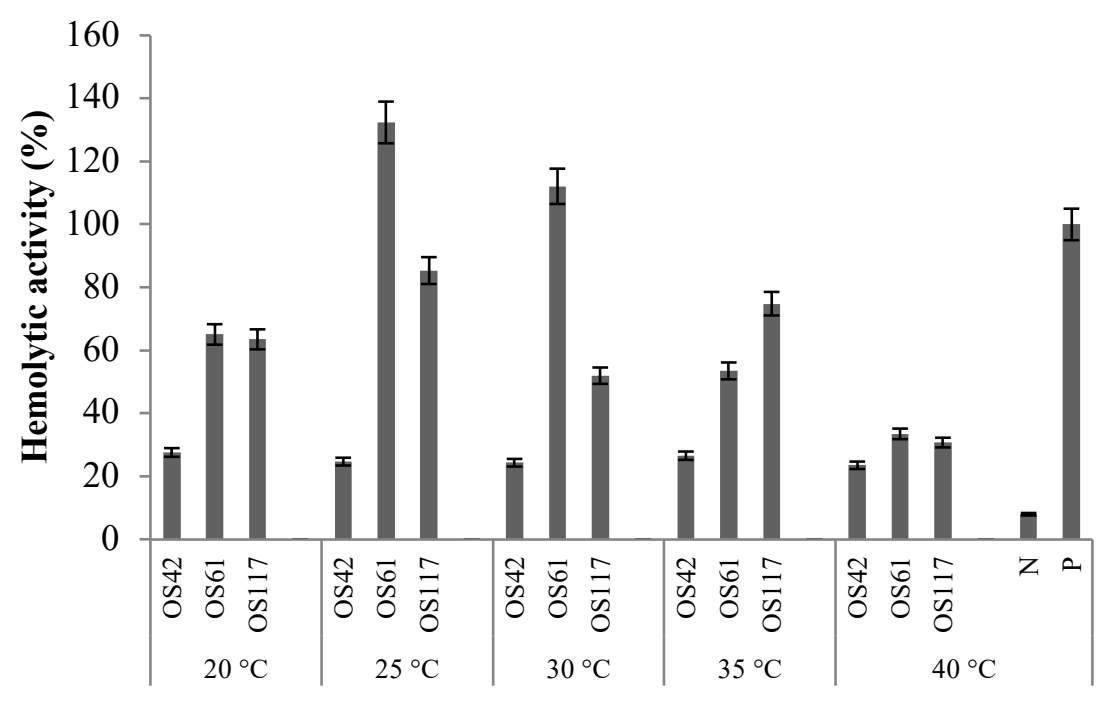

Temperature $\left({ }^{\circ} \mathrm{C}\right)$

Error bars: $\pm 1 \mathrm{SE}$

Fig. 4. Influence of temperature $\left({ }^{\circ} \mathrm{C}\right)$ on hemolysin formation; $\mathrm{N}=$ negative control, $\mathrm{P}=$ positive control 


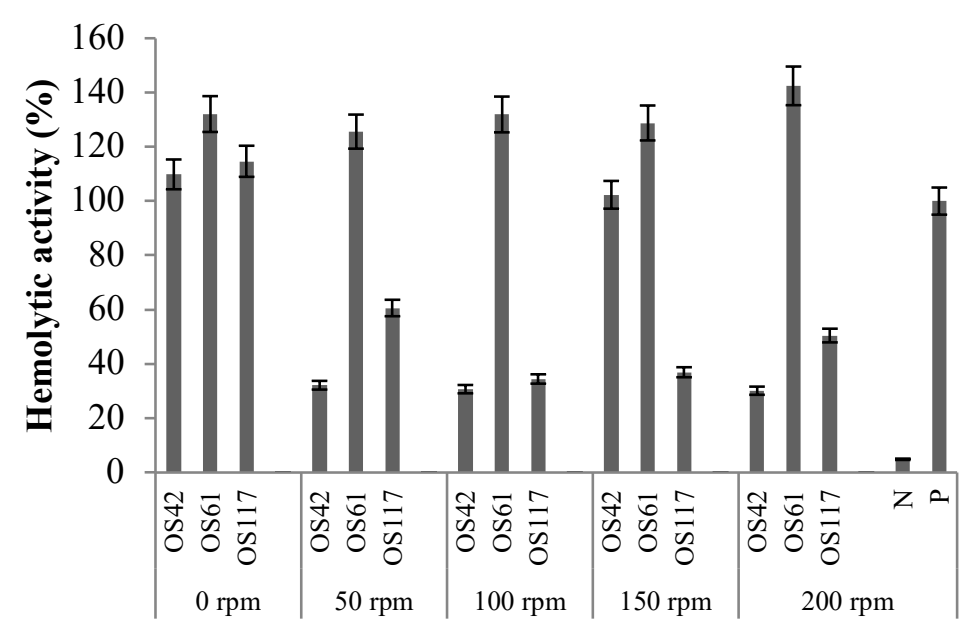

Agitation speed (rpm)

Error bars: $\pm 1 \mathrm{SE}$

Fig. 5. Influence of agitation speed (rpm) on hemolysin formation; $\mathrm{N}=$ negative control, $\mathrm{P}=$ positive control

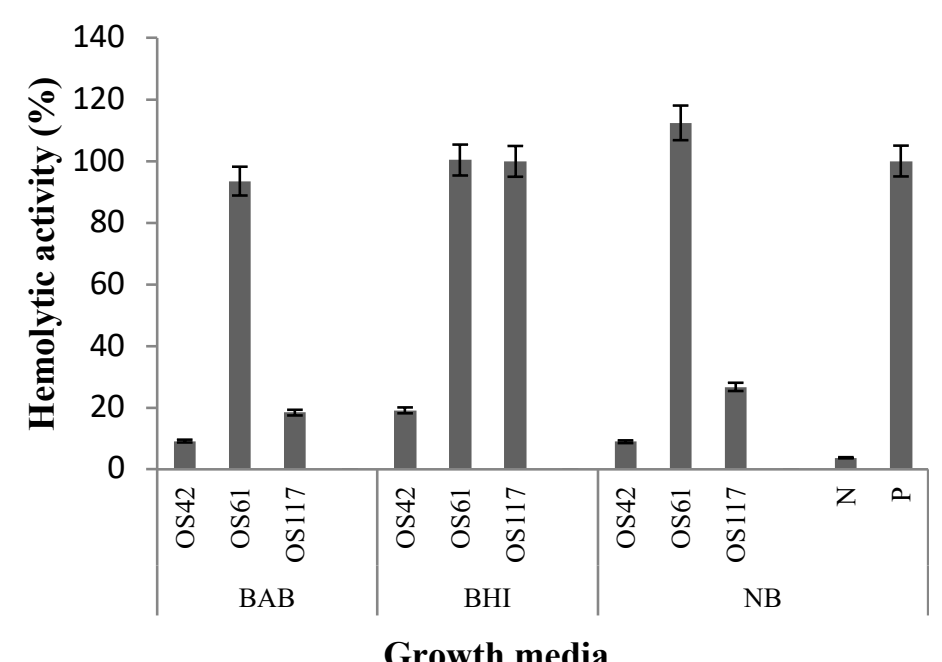

Error bars: $\pm 1 \mathrm{SE}$

Fig. 6. Effect of growth media on hemolysin production; $\mathrm{N}=$ negative control; $\mathrm{P}=$ positive control; $\mathrm{BAB}=$ Blood agar broth; $\mathrm{BHI}=$ Brain heart infusion broth; $\mathrm{NB}=$ Nutrient broth

3.7 Examination of the relationship between bacterial growth and hemolysin production

The time progression of hemolysin synthesis and growing line of tested Alcaligenes strains was observed in Figure 7. All the bacterial isolates were cultured at optimum conditions and monitored for growth and hemolysin synthesis for 56 h. Alcaligenes faecalis strain OS42 and Alcaligenes faecalis strain OS61 reached optimum hemolysin production at $20 \mathrm{~h}$ with $77 \%$ and $79 \%$ hemolytic activity, respectively, which corresponded with the early logarithmic growth of the strains. Meanwhile, optimal hemolysin production was achieved at $36 \mathrm{~h}$ by Alcaligenes faecalis strain OS117 with $85.3 \%$ hemolytic activity. Double peaks of hemolytic activity were observed in Alcaligenes faecalis OS42 at $20 \mathrm{~h}$ and $44 \mathrm{~h}$ of incubation and in Alcaligenes faecalis OS117 at 28 $\mathrm{h}$ and $36 \mathrm{~h}$. Growth and hemolysin production by Alcaligenes faecalis OS42 increased until $44 \mathrm{~h}$, 
when a reduction in hemolysin synthesis was observed. Contrarily, there was a sharp decline in hemolysin production by Alcaligenes faecalis OS61 after it reached its peak at $20 \mathrm{~h}$, although the bacterial growth continued. Hemolysin production by Alcaligenes faecalis OS117 increased as the incubation time increased until $48 \mathrm{~h}$, and after that, the production rate decreased with time.

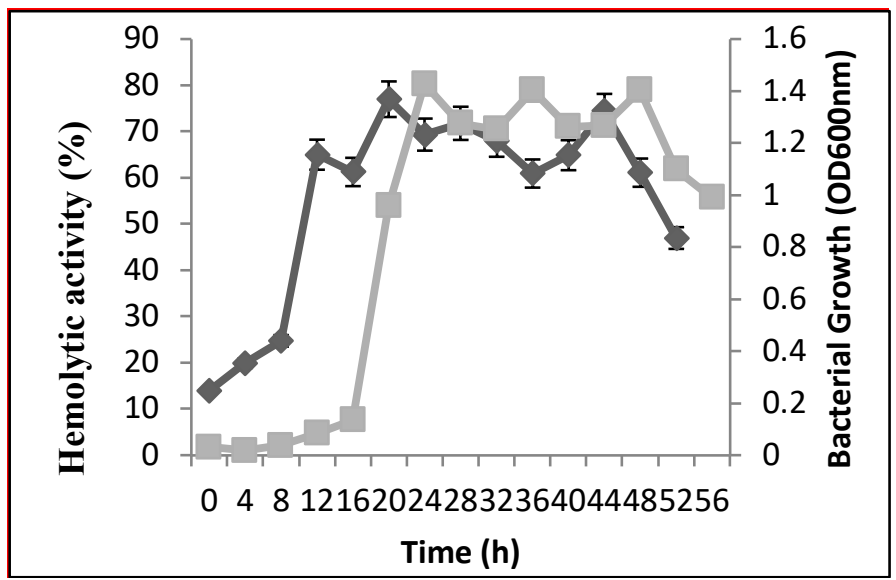

(a)

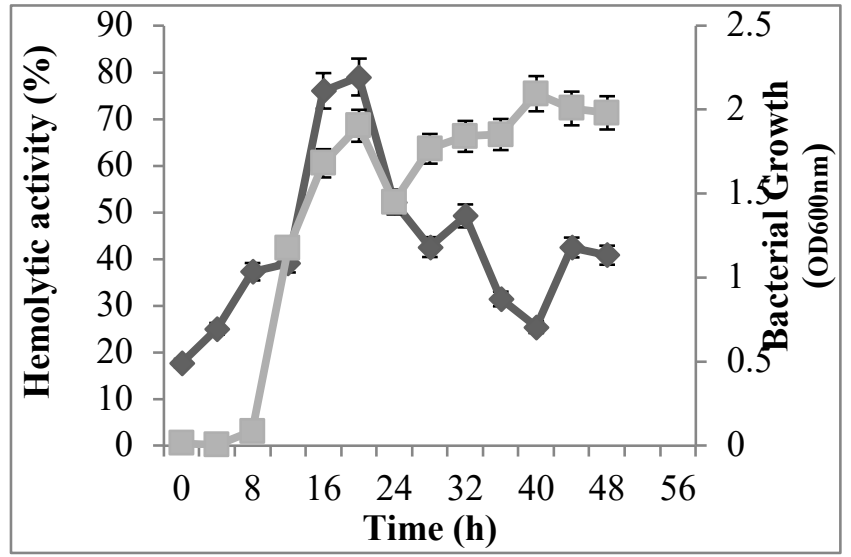

(b)

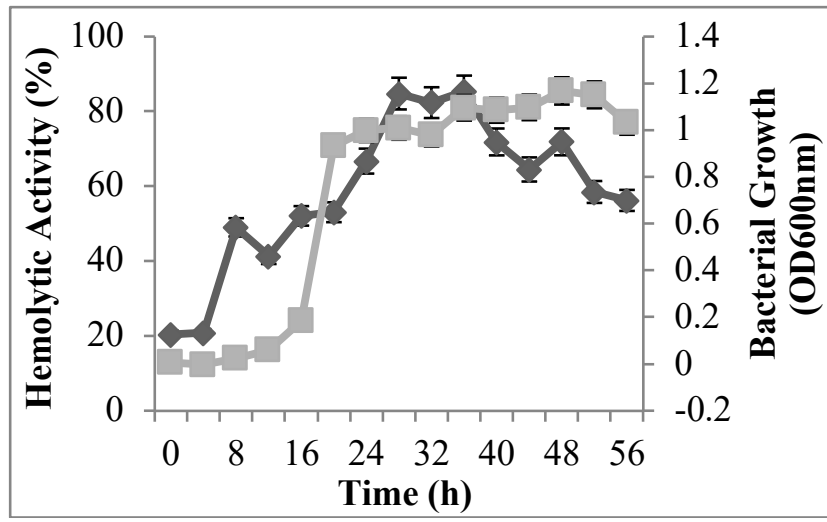

(c)

Error bars: $\pm 1 \mathrm{SE}$

Fig. 7. Relationship between bacterial growth and hemolysin formation by (a) Alcaligenes faecalis strain OS42, (b) Alcaligenes faecalis strain OS61, and (c) Alcaligenes faecalis strain OS117; time versus biomass (dotted line), time versus hemolytic activity (straight). 


\subsection{Effects of various treatments on crude hemolysin}

The effects of different treatments on hemolysin activity by Alcaligenes strains were investigated, and the results are shown in Table 1 . The treatment substances used were $10 \mu \mathrm{g} / \mathrm{ml}$ cholesterol, 5 $\mathrm{mM} \mathrm{AlCl} 3,0.1 \mathrm{mM}$ of EDTA, $5 \mathrm{mM}$ of $\mathrm{MgCl}_{2}, 5 \mathrm{mM}$ of $\mathrm{NaCl}, 5 \mathrm{mM}$ of $\mathrm{CaCl}_{2}$ and $5 \mathrm{mM}$ of $\left(\mathrm{NH}_{4}\right)_{2} \mathrm{SO}_{4}$. These treatments had variable effects on the hemolytic activity; $5 \mathrm{mM}$. $\mathrm{AlCl}_{3}$ had the highest inhibitory effect $(65.3 \%)$ on the hemolytic activity of the crude hemolysin. The hemolytic activity of the untreated hemolysin served as the positive control.

Table 1. Effect of different treatments on crude hemolysin

\begin{tabular}{|l|c|}
\hline $\begin{array}{l}\text { Treatment } \\
\text { reagents }\end{array}$ & $\begin{array}{c}\text { Hemolytic activity (\% } \\
\pm \text { S.D) }\end{array}$ \\
\hline $\begin{array}{l}10 \mu \mathrm{g} / \mathrm{ml} \\
\text { Cholesterol }\end{array}$ & $71.23 \pm 0.12$ \\
\hline $5 \mathrm{mM} \mathrm{AlC}$ & \\
\hline $0.1 \mathrm{mM} \mathrm{EDTA}$ & $65.30 \pm 0.08$ \\
\hline $5 \mathrm{mM} \mathrm{MgCl}$ & $81.28 \pm 0.16$ \\
\hline $5 \mathrm{mM} \mathrm{NaCl}$ & $81.96 \pm 0.55$ \\
\hline $5 \mathrm{mM} \mathrm{CaCl}$ & $80.37 \pm 0.18$ \\
\hline $5 \mathrm{mM}\left(\mathrm{NH}_{4}\right)_{2} \mathrm{SO}_{4}$ & $77.85 \pm 0.34$ \\
\hline Untreated & $79.91 \pm 0.42$ \\
\hline
\end{tabular}

Key: $\mathrm{SD}=$ standard deviation; $\mathrm{AlC}_{3}=$ aluminium chloride, $\mathrm{EDTA}=$ ethylene diamine tetraacetic acid, $\mathrm{MgCl}_{2}=$ magnesium chloride, $\mathrm{NaCl}=$ sodium chloride, $\mathrm{CaCl}_{2}=$ calcium chloride, $\left(\mathrm{NH}_{4}\right)_{2} \mathrm{SO}_{4}=$ ammonium sulphate.

\section{Discussion}

For survival, microorganisms tend to adapt to environmental conditions, and for their growth and viability, they develop mechanisms to utilize available substrates. One of the mechanisms is the production of hemolysin by the microorganisms, which is associated with untreated abattoir wastewater, containing 32.5\% of blood (Aniebo et al., 2011). Hemolysin plays a significant role in controlling infectious diseases (Zhang et al., 2005; Rahman et al., 2010), and it functions as a toxin (Sato et al., 2012). Therefore, it is used as a molecular marker for pathogenicity, primarily in clinical isolates. The hemolytic activities in the environmental microorganisms are steadily being documented (Rajesh et al., 2013). The present study, using PCR, demonstrates the optimization of hemolysin formation by $A$. faecalis strains isolated from a significant city abattoir wastewater plant in Akure, Nigeria. The evolutionary analyses (Figure 1) showed that the strains OS61 and OS117 were more closely related compared with A. faecalis strain OS42.

The genus Alcaligenes has long been known as a contrivance of several metabolites as well as hydrolytic enzymes (Bharali et al., 2011; Naeem et al., 2017), but its hemolysin synthesis has only been connected to the biosurfactant formation, but petite reports have appeared on the optimization and characterization of this enzyme. Furthermore, it is known that the appearance of enzymes by microorganisms is controlled by multiple variables (Fatokun et al., 2016). Therefore, 
to obtain a prime enzymatic activity, it is essential to validate and measure the impact of such variables.

The size of the inoculum is a vital variable that determines microbial growth. We observed optimal hemolysin formation with the most petite sizes of the inoculum among an array of inoculum percentage volumes; A. feacalis strains OS42, OS61, and OS117 produced hemolysin optimally at $0.5 \% \mathrm{v} / \mathrm{v}, 2 \% \mathrm{v} / \mathrm{v}$, and $1 \% \mathrm{v} / \mathrm{v}$ inoculum sizes. This is supported by Jaapar et al. (2011), who have shown that a high substrate to cell ratio could lead to a prolonged growth phase, extending the period of metabolite production. The long period of metabolite production indicates a higher yield of the metabolite. In addition, more culture densities may reduce extracellular substance synthesis because the cell replication may have used up most of the nutrients leaving behind a minuscule amount of nutrients for cellular demands (Nwodo et al., 2013).

$\mathrm{pH}$ is a part of the critical variables that determine the best enzymatic activities. Most enzyme activities and movements through the cell membrane are subjective to the original $\mathrm{pH}$ of the growth media (Gupta \& Kar, 2008; Ahmad et al., 2017; Yusuf et al., 2019). Olson (1993) has reported that the metabolic activities of microorganisms, the production of genes, and their expression are $\mathrm{pH}$-dependent as a reaction to their outer milieu. In addition, the bacterial protein syntheses and their processes are tuned in line with both the inner and outer $\mathrm{pH}$ of a system. The original $\mathrm{pH}$ of the production medium regulates the oxidation-reduction potential in the cells affecting nutrient absorption and enzyme production. In this study, optimal hemolysin synthesis was observed at $\mathrm{pH}$ 7.0 in A. faecalis strains OS61 and OS117, as well as at pH 9.0 for A. faecalis OS42. In contrast, Sato et al. (Sato et al., 2012) reported pH 6.0 was suitable for hemolysin formation in Prevotella oris. Funk et al. (1996) concurred with our results in which maximum hemolytic activity was found within the $\mathrm{pH}$ range of 5 - 9. Considerable differences in the optimal $\mathrm{pH}$ of hemolysin synthesized by different bacterial isolates have been reported (Takada et al., 2003). This variable optimal initial $\mathrm{pH}$ for hemolysin formation in other bacterial species may be because of the variations in media composition and microbial and sample differences (Shu and Lung, 2004).

The bacterial incubation temperature is the crucial player for prime enzyme synthesis, and this may be due to the microbial protein modification influenced by differential incubation temperatures (Juturu and $\mathrm{Wu}, 2014$ ). Ray et al. (2007) have reported that when incubation temperature is not optimal, metabolic turnovers are lower, resulting in growth retardation and reduced enzyme production and activity. In the present study, optimal hemolysin production was recorded at $25^{\circ} \mathrm{C}$ for $A$. faecalis strains OS61 and OS117. This is not in agreement with Hang'ombe et al. (2006), who have reported the optimal temperature for hemolysin production by Clostridium chauvoei at $10{ }^{\circ} \mathrm{C}$ and a significant reduction of over $80 \%$ productivity at $30{ }^{\circ} \mathrm{C}$. Disparities in the incubation temperature for the enzyme production may be accredited to different strains among microbial species and compliance with the temperature range and the environmental growth conditions of the bacteria (Techapun et al., 2002).

The optimal agitation speed for hemolysin synthesis varied among the studied bacterial strains. The observed high agitation speed $(200 \mathrm{rpm})$ for hemolysin production by A. faecalis strain OS61 may result from the maximum oxygen transfer in the growth medium. It is known that the agitation speed influences the aeration level of the bacterial cells. It determines the dissolved 
oxygen level required for the respiration of the bacterial cells and subsequently affects enzyme production in batch fermentation (Jang and Chang, 2005). However, other studies have highlighted that a high agitation speed may lead to solid shear stress and adversely affect growth (Balan et al., 2013; Xia et al., 2014). This is in line with our observation of A. faecalis strains OS42 and OS117.

The different growth media compositions significantly impacted hemolysin synthesis and conservation of activity. The studied bacterial strains showed optimal hemolysin production in various growth media. Hang'ombe et al. (2006) have reported an unclarity of variation in hemolysin activity associated with different growth media. This may be due to a specific protein carrier requirement by individual microorganisms. Marchlewicz and Duncan (1982) have shown that Group B streptococcal hemolysin needed the availability of particular proteins as carriers for conservation of its activity. An induction with streptolysin S may happen during the availability of various proteins (Zhu et al., 2017). Funk et al. (1996) have also reported that the lack of specific proteins may result in reduced transporters of hemolysin, justifying the absence of hemolysin synthesis indefinite media.

The bacterial growth kinetics have suggested that hemolysin is synthesized during the logarithmic and primary stationary growth phase (Sato et al., 2012). Higher hemolytic activity has been recorded from the crude hemolysin obtained from the early logarithmic growth phase than the crude hemolysin obtained from the stationary phase. The same pattern of hemolysin synthesis has been revealed by Aggregatibacter actinomycetemcomitans (Kimizuka et al., 1996), Prevotella intermedia (Beem et al., 1998), Porphyromonas gingivalis (Deshpande \& Khan, 1999), Prevotella nigrescens (Silva et al., 2004) and Prevotella oris (Sato et al., 2012). In our study, the reduced hemolysin synthesis at the late logarithm phase of incubation may be due to many factors, such as nutrient exhaustion and proteolysis. (Papagianni and Moor-Young, 2002).

Crude hemolysin from the bacterial strains was treated with cholesterol and EDTA. The hemolytic activity did not enhance by any of these treatments. Funk et al. (1996) has also reported a non-impact of cholesterol on the hemolytic activity of hemolysins from Actinomyces pyogenes. This contrasts with Alouf (1980) and Jacobs et al. (1994), who have reported a significant effect of cholesterol on hemolysins from Listeria monocytogenes and Streptococcus suis. Former studies have revealed that hemolysin complexes with cholesterol result in a decline in cytolytic activity (Prigent and Alouf, 1976). Sato et al. (2012) has suggested that the variance in the effect of cholesterol on different hemolysins may be due to specific differences in the membrane damage caused by individual hemolysin produced. Additional studies are needed to study the mechanism of the formation of hemolysins in the abattoir wastewater of Nigeria.

\section{Conclusion}

Our results suggest the occurrence of hemolytic Alcaligenes species in the final wastewater effluent of Onyearugbulem abattoir in Akure, Nigeria. Our study has provided critical information on the best conditions for hemolysin synthesis in A. feacalis strains by assessing their hemolytic activity using variable cultivation parameters. The traditional optimization for hemolysin formation in $A$. feacalis strain OS117 resulted in $85.31 \%$ activity compared with $100 \%$ lysis with Triton-X 100. In A. feacalis strain, OS117 hemolysin formation is supported at neutral $\mathrm{pH}, 25^{\circ} \mathrm{C}$, 
in stationary cultures, in the early logarithmic phase using brain heart infusion broth by $1 \% \mathrm{v} / \mathrm{v}$ inoculum. Further studies about purification, mechanisms of action, and the molecular structure of hemolysins formed in Alcaligenes species are required.

\section{ACKNOWLEDGMENTS}

The authors are grateful for the financial support offered by the Organization for Women in Science for the Developing World (OWSD) and Swedish International Development Cooperation Agency (SIDA).

\section{References}

Abo-Amer, A.E.; El-Shanshoury, E.R.; \& Alzahrani, O.M. (2015) Isolation and Molecular Characterization of Heavy Metal-Resistant Alcaligenes faecalis from Sewage Wastewater and Synthesis of Silver Nanoparticles, Geomicrobiology Journal, 32(9): 836-845.

Ahmad, S.A.; Shamaan, N.A.; Syed, M.A.; Khalid, A.; Rahman, N.A.; Khalil, K.A.; Dahalan, F.A.; \& Shukor, M.Y. (2017) Meta-cleavage pathway of phenol degradation by Acinetobacter sp. strain AQ5NOL 1. Rendiconti Lincei, 28: 1-9.

Akinro, A.O.; Ologunagba, I.B.; \& Yahaya, O. (2009) Environmental implication of unhygienic operation of a city abattoir in Akure, Western Nigeria. Journal of Engineering and Applied Science, 4: 61-63.

Alouf, J.E. (1998) Streptococcal toxins (streptolysin 0. streptolysins, erythrogenic toxin), Pharmacology and Therapy, 11: 661-717.

Aniebo, A.O.; Wekhe, S.N.; \& Okoli, I.C. (2011) Abattoir blood waste generation in River state and its environmental implications in the Niger Delta. Toxicology and Environmental Chemistry, 91: 619-625.

Balan, V.; Jin, M.; Culbertson, A.; \& Uppugundla, N. (2013) The saccharification step: Trichoderma reseei cellulase hyper producer strains. In Lignocellulose Conversion Enzymatic and Microbial Tools for Bio-ethanol Production (eds. Faraco, V.), Springer: Berlin/Heidelberg, Germany, 65-92.

Beem, J.E.; Nesbitt, W.E.; \& Leung, K.P. (1998) Identification of hemolytic activity in Prevotella intermedia, Oral Microbiology and Immunology, 13: 97-105.

Behera, B.C.; Yadav, H.; Singh, S.K.; Sethi, B.K.; Mishra, R.R.; Kumari, S.; \& Thatoi, H. (2017) Alkaline phosphatase activity of a phosphate solubilizing Alcaligenes faecalis, isolated from Mangrove soil, Biotechnology Research and Innovation, 1(1): 101-111.

Bergey, D.; Holt, H.; \& John, G. (Eds.) (2000) Bergey's manual of determinative bacteriology, Philadelphia: Lippincott Williams \& Wilki. 
Behera, B.C.; Yadav, H.; Singh, S.K.; Sethi, B.K.; Mishra, R.R.; Kumari, S.; \& Thatoi, H. (2017) Alkaline phosphatase activity of a phosphate solubilizing Alcaligenes faecalis, isolated from Mangrove soil, Biotechnology Research and Innovation, 1(1): 101-111.

Bhakdi, S.; Tranum-Jensen, J.; \& Sziegoleit, A. (1985) Mechanism of membrane damage by streptolysin-O, Infections and Immunity, 47: 52-60.

Bharali, P.; Das, S.; Konwar, B.K.; \& Thakur, A.J. (2011) Crude biosurfactant from thermophilic Alcaligenes faecalis Feasibility in petro-spill bioremediation. International Biodeterioration and Biodegradation, 65: 682-690.

Chukwu, O.; Mustapha, H.I.; \& Abdul-Gafar, H.B. (2008) The effect of Minna waste on surface water quality. Environmental Research Journal, 2: 339-342.

Coker, A.O.; Olugasa, B.O.; \& Adeyemi, A.O. (2001) Abattoir Effluent Quality in South Western Nigeria. Proceedings of the 27th WEDC Conference, Lusaka, Zambia, 20-21, August 2001, 1-4.

Das, R.; Sinha, P.; \& Kar, D. (2016) Characterization of lasB and $p l c \mathrm{H}$ gene from Pseudomonas aeruginosa isolates in Silchar, Clinical Microbiology, 5: 239-242.

Deshpande, R.G.; \& Khan, M.B. (1999) Purification and characterization of hemolysin from Porphyromonas gingivalis A7436. FEMS Microbiology Letters, 176: 387-394.

El Samak, M.; Solyman, S.M.; \& Hanora, M. (2018) Antimicrobial activity of bacteria isolated from Red Sea marine invertebrates, Biotechnology Reports, 19: e00275: 1-7.

Fatokun, E.N.; Nwodo, U.U.; \& Okoh, A.I. (2016) Classical Optimization of Cellulase and Xylanase Production by a Marine Streptomyces Species. Applied Science, 6: 1-14.

Funk, P.G.; Staats, J.J.; Howe, M.; Nagaraja, T.G.; \& Chengappa, M.M. (1996) Identification and partial characterization of an Actinomyces pyogenes hemolysin. Veterinary Microbiology, 50: 129-142.

Gupta, U.; \& Kar, R. (2008) Optimization and scale-up of cellulase free endo xylanase production by solid-state fermentation on corn cob and by immobilized cells of thermotolerant bacterial isolates. Jordan Journal of Biological Science, 1: 129-134.

Hang'ombe, B.M.; Kohda, T.; Mukamoto, M.; \& Kozaki, S. (2006) Purification and sensitivity of Clostridium chauvoei hemolysin to various erythrocytes, Comparative Immunology, Microbiology and Infectious Diseases, 29: 263-268. 
Hussain, T.; Edel-Hermann, V.; Roohi, A.; Munir, S.; Ahmed, I.; Khan, J.; Yong Kim, K.; \& Anees, M. (2013) Biochemical characterization and identification of bacterial strains isolated from drinking water sources of Kohat, Pakistan, African Journal of Microbiology Research, 7: 1579-1590.

Yusuf, I.; Ahmad, S.A.; Phang, L.Y.; Yasid, N.A.; and Shukor, M.Y. (2019) Effective keratinase production by gellan gum-immobilized Alcaligenes sp. AQ05-001 uses heavy metalfree and polluted feather wastes as substrates. Biotech, 9(1):1-12.

Jaapar, S.Z.; Kalil, M.S.; Ali, M.; \& Anuar, N. (2011) Effects of Age of Inoculum, Size of Inoculum and Headspace on Hydrogen Production using Rhodobacter sphaeroides. Bacteriology Journal, 1: 16-23.

Jacobs, A.A.C.; Loefen, P.L.W.; Van den Berg, A.J.G.; \& Storm, P.K. (1994) Identification, purification, and characterization of a thiol-activated hemolysin (suilysin) of Streptococcus suis. Infections and Immunity, 62: 1742-1748.

Jang, H.D.; \& Chang, K.S. (2005) Thermostable cellulases from Streptomyces sp.: Scale-up production in a 50-1 fermenter. Biotechnology Letters, 27: 239-242.

Jiajun, X.; Linjun, G.; Shipeng, W.; \& Yitong, L. (2010) Comparative impact of cadmium on two phenanthrene-degrading bacteria isolated from cadmium and phenanthrene co-contaminated soil in China. Journal of Hazardous Materials, 174: 818-823.

Jones, C.M.; \& Niederweis, M. (2011) Mycobacterium tuberculosis can utilize heme as an iron source. Journal of Bacteriology, 193: 1767-1770.

Ju, S.; Lin, J.; Zheng, J.; Wang, S.; Zhou, H.; \& Sun, M. (2016) Alcaligenes faecalis ZD02, a novel nematicidal bacterium with an extracellular serine protease virulence factor, Applied Environmental Microbiology, 82: 2112-2120.

Juturu, V.; \& Wu, J.C. (2014) Microbial cellulases: Engineering, production, and applications. Renewable and Sustainable Energy Reviews, 33: 188-203.

Kimizuka, R.; Miura, T.; \& Okuda, K. (1996) Characterization of Actinobacillus actinomycetemcomitans hemolysin. Microbiology and Immunology, 40: 717-723.

Ktari, N., Trabelsi, I., Bardaac, S., Trikib, M., Bkhairiaa, I.; Ben, R.; Salema, S.; Nasria, M.; \& Ben-Salahb, R. (2017) Antioxidant and hemolytic activities, and effects in rat cutaneous wound healing of a novel polysaccharide from fenugreek (Trigonellafoenum-graecum) seeds, International Journal of Biological Macromolecules, 95: 625-634. 
Marchlewicz, B.A.; \& Duncan, J.L. (1982) Lysis of erythrocytes by a hemolysin produced by a Group B Streptococcus sp., Infections, and Immunity, 34: 787-794.

Naeem, A.H.; Mumtaz, S.; Haleem, A.; Qazi, M.A.; Malik, Z.A.; Dasti, J.I.; \& Ahmed, S. (2017) Isolation and Molecular Characterization of Biosurfactant-Producing Bacterial Diversity of Fimkassar Oil Field, Pakistan, Arabian Journal of Science and Engineering, 42: 2349-2355.

Nduka, O. (2011) Environmental Microbiology of Aquatic and Waste Systems, 1st ed, Springer, Netherlands.

Nwodo, U.U.; Rumbold, K.; Agunbiade, M.O.; Green, E.; Nwamadi, M.; \& Okoh, A.I. (2013) Characterization of an Exopolymeric Flocculant Produced by a Brachybacterium sp. Materials, 6:1237-1254.

Ogbonna, D.N.; \& Ideriah, T.J.K. (2014) Effect of Abattoir Waste Water on Physico-chemical Characteristics of Soil and Sediment in Southern Nigeria. Journal of Science Research Reports, 3: 1612-1632.

Olson, E.R. (1993) Influence of $\mathrm{pH}$ on bacterial gene expression. Molecular Microbiology, 8: 514.

Papagianni, M.; and Moo-Young, M. (2002) Protease secretion in glucoamylase producer Aspergillus niger cultures: Fungal morphology and inoculum effects. Protease secretion in glucoamylase producer Aspergillus niger cultures: Fungal morphology and inoculum effects. Process Biochemistry, 37: 1271-1278.

Prigent, D.; \& Alouf, J.E. (1976) Interaction of streptolysin O with sterols. Biochimica et Biophysica Acta (BBA) - Biomembranes, 443: 288-300.

Public Health England, (2015) Health Protection Representative, 9: 1-1221.

Rahman, A.; Srivastava, S.S.; Sneh, A.; Ahmed, N.; \& Krishnasastry, M.V. (2010) Molecular characterization of tlyA gene product, Rv1694 of Mycobacterium tuberculosis: a non-conventional hemolysin and a ribosomal RNA methyl transferase, BMC Biochemistry, 11: 35-43.

Rajesh, T.; Jong-Min, J.; Yong-Hyun, K.; Hyun-Joong, K.; Da Hye, Y.; Sung-Hee, P.; KwonYoung, C.; Yun-Gon, K.; Jaebum, K.; Seunho, J.; Hyung-Yeon, P.; \& Yung-Hun, Y. (2013) Functional analysis of the gene SCO1782 encoding Streptomyces hemolysin (S-hemolysin) in Streptomyces coelicolor M145, Toxicology, 71: 159-165.

Rajeshkumar, K.; \& Jayachandran, K. (2004) Treatment of dairy wastewater using a selected bacterial isolate, Alcaligenes sp. MMRR7. Applied Biochemistry and Biotechnology, 118, 65-72. 
Ray, A.K.; Bairagi, A.; Ghosh, K.S.; \& Sen, S.K. (2007) Optimization of fermentation conditions for cellulase production by Bacillus subtilis CY5 and Bacillus circulans TP3 isolated from the fish gut. Acta Ichthyologica et Piscatoria, 3: 47-53.

Sato, T.; Kamaguchi, A.; \& Nakazawa, F. (2012) Purification and characterization of hemolysin from Prevotella oris, Journal of Oral Bioscience, 54: 113-118.

Shu, C.H.; \& Lung, M.Y. (2004) Effect of $\mathrm{pH}$ on the production molecular and weight distribution of exopolysaccharide Antrodia by camphorate in batch cultures. Process Biochemistry, 39: 931-937.

Silva, T.A.; Noronha, F.S.M.; Farias, L.D.; \& Carvalho, M.A.R. (2004) In-vitro activation of the hemolysin in Prevotella nigrescens ATCC 33563 and Prevotella intermedia ATCC 25611, Research in Microbiology, \&: 31-38.

Singh, V.; Chaudhary, D.; Mani, I.; Somvanshi, P.; Rathore, G. \& Sood, N. (2010) Molecular identification and codon optimization analysis of significant virulence encoding genes of Aeromonas hydrophila. African Journal of Microbiology Research, 4: 952-957.

Springer Dordrecht Heidelberg, London, New York, 1- 324.

Stipcevic, T.; Piljac, T.; \& Isseroff, R. (2005) Di-rhamnolipid from Pseudomonas aeruginosa displays differential effects on human keratinocyte and fibroblast cultures. Journal of Dermatological Science, 4: 141-143.

Takada, K.; Fukatsu, A.; Otake, S.; \& Hirasawa, M. (2008) Isolation and characterization of hemolysin activated by reductant from Prevotella intermedia. FEMS Immunology and Medical Microbiology, 35: 43-47

Tapi, A.; Chollet-Imbert, M.; Scherens, B.; \& Jacques, P. (2010) New approach for detecting non-ribosomal peptide synthetase genes in Bacillus strains by polymerase chain reaction, Applied Microbiology, and Biotechnology, 85: 1521-1531.

Techapun, C.; Charoenrat, T.; Poosaran, N.; Watanabe, M.; \& Sasaki, K. (2002) Thermostable and alkaline-tolerant cellulase-free xylanase produced by thermotolerant Streptomyces sp. Ab106. Journal of Bioscience and Bioengineering, 93: 431-433.

Wongwongsee, W.; Chareanpat, P.; \& Pinyakong, O. (2003) Marine Pollution Bulletin, 74: 95104

Xia, X.; Lin, S.; Xia, X.X.; Cong, F.S.; \& Zhong, J.J. (2014) Significance of agitation-induced shear stress on mycelium morphology and lavendamycin production by engineered Streptomyces flocculus. Applied Microbiology and Biotechnology, 98: 4399-4407. 
Xia, Z. (2013) Effect of Tween 80 on the production of curdlan by Alcaligenes faecalis ATCC 31749. Carbohydrate Polymerase, 98: $178-180$.

Zhang, X.; \& Austin, B. (2005) Hemolysins in Vibrio species. Journal of Applied Microbiology, 98: 1011-1019.

Zhu, L.; Olsen, R.J.; Lee, J.D.; Porter, A.R.; DeLeo, F.R.; \& Musser, J.M. (2017) Contribution of Secreted NADase and Streptolysin O to the Pathogenesis of Epidemic Serotype M1 Streptococcus pyogenes Infections, The American Journal of Pathology, 187: 1-9.

Submitted: $\quad 24 / 05 / 2020$

Revised: $\quad 24 / 08 / 2021$

Accepted: $\quad 30 / 08 / 2021$

DOI: $\quad 10.48129 /$ kjs.9406 